\title{
Strategi Peningkatan Mutu Pendidikan Pada Pelaksanaan Pembelajaran Daring Di Masa Pandemi Covid-19 (Survei Online: Pelajar SMA/SMK/MA di Kabupaten Lamongan)
}

\author{
Riza Qomariyah Yansari \\ Program Studi Ekonomi Syariah, Fakultas Ekonomi dan Bisnis Islam, Universitas Islam Negeri Sunan Ampel \\ Surabaya
}

\begin{abstract}
The purpose of online learning is to serve students so that learning becomes quality so that it can be accessed through a network and can be reached widely. This study has the aim of testing strategies in improving the quality of online learning that are studied using the SPSS 16.0 data processing application, using 33 respondents consisting of high school / vocational / MA students in Lamongan Regency. The results of the study show that the strategy to improve the quality of education has an important role in online learning during the current pandemic. The Lamongan District Education Office in collaboration with the Jagoapa application provider and the Smart Foundation has launched a learning application called e-learning Jago Sinau which is used to help facilitate the teaching and learning process in the midst of the Covid-19 pandemic. The Lamongan Regency Regional Library Service also launched a digital library application called iLamongan which can be used to read e-books online and offline making it easier for students to carry out online learning, there are 12 applications that can also be accessed by students to study at home, among others; Our Desk, Learning House, Icando, IndonesiaX, Google for Education, Quipper School, Teacher Room, Your School, Smart Class, Cisco Webex, Microsoft Offuce, and Zenius.
\end{abstract}

Keywords : Strategy, Improving the Quality of Education, Online Learning

Abstrak : Tujuan dari pembelajaran daring untuk melayani pelajar agar pembelajaran menjadi bermutu sehingga dapat diakses melalui sebuah jaringan dan dapat dijangkau secara luas. Penelitian ini memiliki tujuan untuk menguji strategi dalam peningkatan mutu pembelajaran daring yang diteliti menggunakan aplikasi pengolahan data SPSS 16.0, dengan menggunakan responden 33 orang yang terdiri dari pelajar SMA/SMK/MA di Kabupaten Lamongan. Hasil dari penelitian menunjukkan bahwa strategi peningkatan mutu pendidikan memiliki peran penting pada pembelajaran daring ketika masa pandemi seperti sekarang. Dinas Pendidikan Kabupaten Lamongan melakukan kerjasama dengan penyedia aplikasi Jagoapa dan Smart Foundation telah launching sebuah aplikasi pembelajaran yang bernama e-learning Jago Sinau dimanfaatkan untuk kemudahan dalm membantu proses belajar mengajar di tengah pandemi Covid-19. Dinas Perpustakaan Daerah Kabupaten Lamongan juga meluncurkan aplikasi perpustakaan digital bernama iLamongan yang dapat digunakan untuk membaca e-book secara online maupun offline sehingga memudahkan pelajar dalam melaksanakan pembelajaran daring, adapu 12 aplikasi yang dapat juga diakses para pelajar untuk belajar dirumah antara lain; Meja Kita, Rumah Belajar, Icando, IndonesiaX, Google for Education, Quipper School, Ruang Guru, Sekolahmu, Kelas Pintar, Cisco Webex, Microsoft Offuce, dan Zenius.

Kata Kunci : Strategi, Peningkatan Mutu Pendidikan, Pembelajaran Daring 


\section{Pendahuluan}

Virus Covid-19 atau Corona Virus Disease 19 melanda negara Indonesia sejak Maret 2020, dengan penyebaran yang begitu cepat sehingga sekitar 215 negara di seluruh dunia mengalami krisis kesehatan. Organisasi Kesehatan Dunia atau World Health Organization (WHO) memberikan himbauan kepada seluruh negara agar menghentikan kegiatan untuk sementara waktu yang menimbulkan kerumunan. Pemerintah Indonesia tidak tinggal diam selama Covid-19 merebak, berbagai cara dilakukan untuk mencegah penyebarannya anara lain; beberapa daerah membuat keputusan untuk penutupan akses jalan hingga membatasi aktivitas keluar masuk warga yang ada di daerah tersebut atau social distancing; adanya himbauan untuk pemakaian masker saat keluar rumah, selalu membiasakan diri mencuci tangan menggunakan sabun dengan air mengalir secara rutin dan menjaga jarak dengan minimal jarak satu meter. Sesuai dengan Surat Edaran yang diberikan dari Kementerian Pendidikan dan Kebudayaan Direktorat Pendidikan Tinggi No. 1 Tahun 2020, sesuai instruksi yang disampaikan bahwa dalam upaya untuk mencegah virus Covid-19 yang mulai menyebar di dunia pendidikan saat ini kiat yang dilakukan oleh Pemerintah adalah melaksanakan pembelajaran secara jarak jauh serta dilakukan untuk pelajar agar belajar dari rumah. Tentu saja pandemi Covid-19 ini berdampak ke seluruh faktor kehidupan, mulai dari ekonomi, sosial, dan lain-lain, terutama pada dunia pendidikan yang mana semestinya pembelajaran dilakukan secara langsung tetapi saat ini hanya dapat dilakukan dengan tatap muka melalui maya dan dilakukan secara mandiri dimana pelajar melakukan pembelajaran virtual ini tidak langsung memanfaatkannya karena dirasa butuh waktu untuk menyesuaikan dengan keadaan.

\section{Kajian Literatur}

\section{Strategi}

Menurut Craiq dan Grant yang dimaksud dengan strategi yaitu dalam menerapkan sasaran dan tujuan membutuhkan jangka waktu yang panjang. Sedangkan pendapat dari Morrisey, strategi merupakan sebuah proses yang dilakukan untuk menentukan arah dan tujuan agar mencapai segala misi yang telah direncanakan. Strategi menurut Rangkuti merupakan sebuah alat yang dapat digunakan sehingga mencapai tujuan 
yang sudah ditetapkan. Scholes dan Johnson memberikan pengertian bahwa strategi adalah sebuah arah dan ruang lingkup dari suatu organisasi yang memiliki tujuan dengan waktu jangka panjang sehingga mencapai titik untung serta konfigurasi sumber daya yang ada di lingkungan dan digunakan sebagai pemenuhan kebutuhan yang ada di pasar. Pengertian strategi secara umum adalah suatu pendekatan yang memiliki keterkaitan dengan perencanaan dan eksekusi dalam aktivitas dengan batas waktu ternetu serta merupakan suatu proses dalam menentukan rencana dan menyususn suatu cara yang dilakukan oleh pemimpin puncak sehingga mecapai tujuan jangka panjang. Sehingga dapat diambil kesimpulan bahwa startegi itu sangat

diperlukan dalam mengambil sebuah keputusan, sehingga dengan adanya penerapan strategi yang digunakan dalam penerapan peningkatan mutu untuk pelaksanaan pembelajaran daring pada masa Covid-19 seperti sekarang diperlukan dalam keberlangsungan belajar mengajar dengan sistem virtual dapat sesuai yang diharapkan.

\section{Peningkatan Mutu Pendidikan}

Peraturan Republik Indonesia No. 9 Tahun 2005 yang telah dikeluarkan oleh Pemerintah mengenai Standar Nasional Pendidikan ini dibuat dalam rangka untuk peningkatan mutu pendidikan yang diterapkan di negara Indonesia. Adapun isi dari Peraturan Pemerintah tersebut antara lain; dalam proses pembelajaran diselenggarakan harus secara interaktif, inovatif, dan dapat memotivasi pelajar untuk meningkatkan prestasi serta memberikan ruang dalam kreatifitas dan kemandirian pelajar yang sesuai dengan minat, bakat serta lainnya yang ada di dalam proses kegiatan pembelajaran dilakukan; perencanaan dalam proses pembelajaran yang aktif serta dinamis harus dimiliki oleh setiap satuan pendidikan dalam meningkatkan mutu pendidikan pada pembelajaran. Adapun Peraturan Pemerintah dan Undang-undang yang mengindikasikan mengenai pentingnya dalam memperhatikan mutu pembelajaran yang digunakan untuk peningkatan pendidikan di sekolah, antara lain usaha yang dilakukan oleh Pemerintah harus cepat ditindak lanjuti oleh setiap satuan pendidikan sekolah swasta maupun negeri yang ada di seluruh Indonesia dengan 
mengadakan berbagai macam kegiatan untuk mengembangkan potensi tenaga pendidik yang dapat dilakukan dengan pelatihan, seminar, workshop maupun kegiatan lain yang bermanfaat dan semua kegiatan harus dilakukan secara berkelanjutan untuk menjadikan tenaga pendidik lebih profesional yang memiliki kemampuan dalam meningkatkan mutu pendidikan di institusi pendidikan masingmasing.

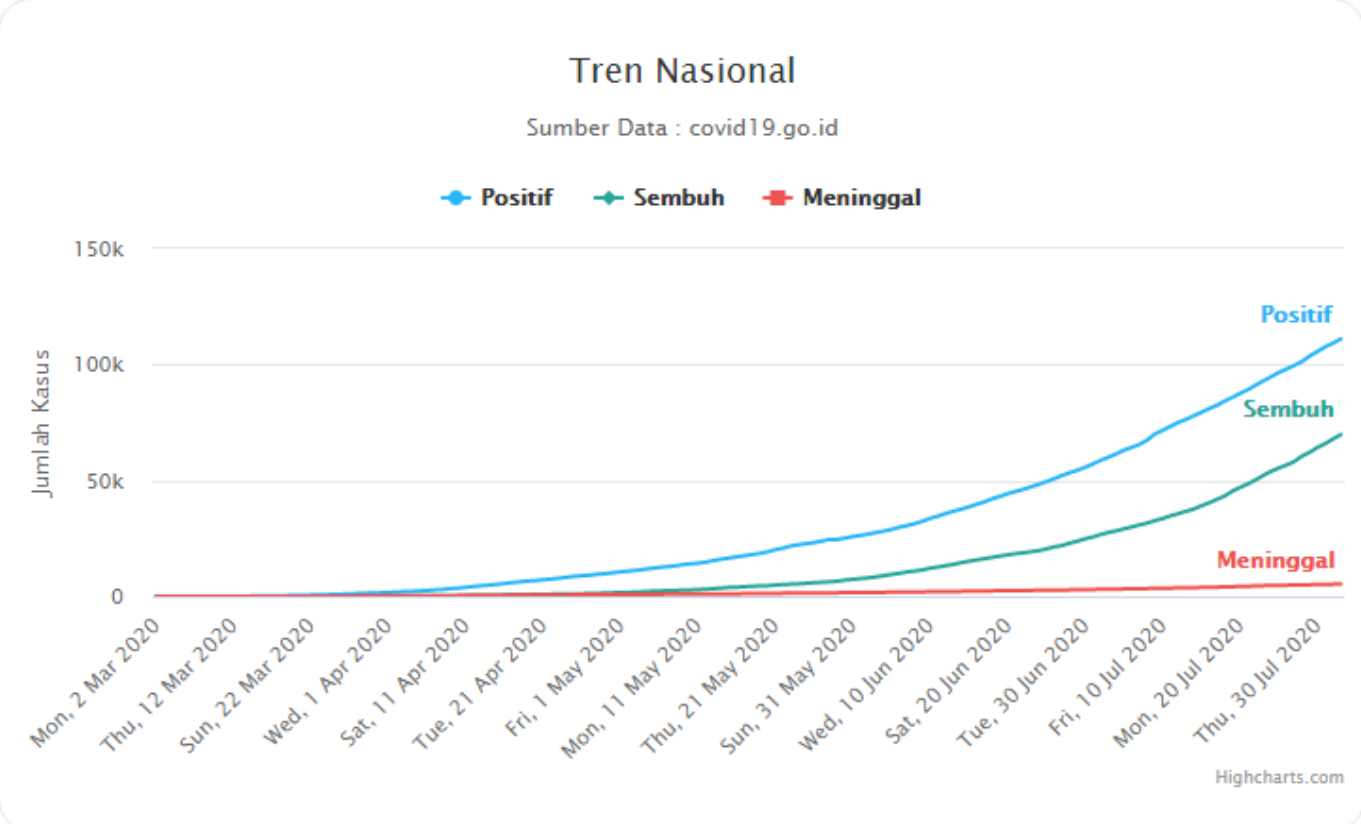

Sumber covid.go.id

Perkembangan Covid-19 per Juli 2020 masih menunjukkan angka 100.000 lebih jumlah kasus positif, angka sekitar 50.000 dengan jumlah pasien yang sembuh. Perlu ditanamkan lagi dalam benak masyarakat bahwa kasus ini masih sangat rentan terjadi kepada siapa saja tidak memandang harta dan umur, karena apabila tidak ada kesadaran di setiap individu maka kasus ini semakin hari akan semakin bertambah dan berdampak ke berbagai sektor, khususnya di bidang pendidikan. Angka kasus pada Covid-19 sampai saat ini per Juni 2021 masih tinggi, diharapkan kepasa pelajar harus mendapatkan dukungan semangat belajar dari diri sendiri dan lingkungan sekitar sehingga tidak menimbulkan rasa malas dan mempengaruhi pola pikir yang disebabkan merebaknya virus ini serta dapat menyulitkan dalam proses pelaksanaan 
belajar di sekolah yang pada akhirnya interaksi pemeblajaran yang seharusnya dilakukan secara langsung kini harus beralih menjadi pembelajaran jarak jauh dengan bertatap muka lewat maya. Kehadiran sebuah lembaga yang bermutu diharapkan oleh semua pihak, karena urgensi perkembangan mutu pendidikan dengan melihat kondisi realita yang saat ini berkembang, tidak dapat ditunda lagi (Mukbulloh, 2011).

Pemerintah telah mengkaji keadaan di masa new normal ini dengan melakukan berbagai strategi untuk meningkatkan mutu pendidikan dengan cara melakukan pembelajaran melalui jarak jauh yang dapat dilakukan secara virtual atau bertatap muka menggunakan layar gawai atau laptop masing-masing pelajar. Kualitas pendidikan dalam suatu institusi pendidikan merupakan sebuah masalah yang perlu digaris bawahi karena penting jika dilihat dari berbagai kondisi dan potensi yang ada, pengembangan dalam pembelajaran harus berorientasi pada pelajar sehingga dalam membangun sistem pembelajaran dapat dilakukan dengan mempertimbangkan beberapa kemungkinan sehingga para pelajar mempunyai sebuah kemampuan yang lebih bervariasi, menarik, dan banyak berinteraksi dalam belajar. Seperti halnya yang dilakukan oleh Pemerintah dalam pengambilan peran untuk menangani masalah ketidakseimbangan proses belajar selama terjadi pandemi Covid-19 yang melanda negara kita, dalam laman resmi Kemendikbud RI yang dilansir yaitu terdapat 12 aplikasi yang dapat diakses para pelajar untuk melaksanakan pembelajaran daring ketika di rumah masing-masing anatara lain; Meja Kita, Rumah Belajar, Icando, IndonesiaX, Google for Education, Quipper School, Ruang Guru, Sekolahmu, Kelas Pintar, Cisco Webex, Microsoft Office, dan Zenius.

\section{Pembelajaran Dalam Jaringan}

Pembelajaran dalam jaringan adalah pembelajaran yang dilakukan menggunakan jaringan, dengan maksud memudahkan pelajar ketika belajar di rumah yang telah diterapkan oleh Pemerintah pada kondisi pandemi Covid-19. Adapun tantangan dalam pembelajaran daring yaitu kemahiran setiap individu dalam menggunakan teknologi dari pendidik maupun peserta didik, Dabbagh N. (2007) menyebutkan ciriciri dari pelajar yang melakukan aktivitas belajar daring antara lain; semangat dalam 
belajar yang kuat karena pelajar dituntut untuk mandiri serta harus menemukan pengetahuan dengan caranya sendiri tanpa harus ada arahan dari tenaga pendidik; literasi terhadap teknologi, sebagai pelajar harus memahami terlebih dulu mengenai teknologi yang akan dipakai dalam pembelajaran daring; kemampuan interpersonal sangat diperlukan agar tetap menjalin interaksi dengan pelajar yang lain dan harus tetap dilatih karena di masa mendatang itu sangat berguna ketika sudah terjun langsung ke masyarakat; melakukan kolaborasi dengan lingkungan sekitar juga sangat diperlukan untuk mendukung pembelajaran dalam jaringan; keterampilan pada setiap individu untuk belajar masing-masing karena dalam proses melakukan belajar para pelajar dituntut untuk dapat mengetahui, mencari, menemukan solusi, menyimpulkan dan menyampaikan terkait apa yang telah diperolehnya dari hasil belajar mandiri.

Keputusan Pemerintah Kabupaten Lamongan dalam melaksanakan pembelajaran daring karena adanya himbauan dari Kemendikbud RI yang mengharuskan semua pelajar melaksanakan pemebelajaran secara daring seiring berjalannya waktu kondisi di Indonesia karena pandemi Covid-19 ini yang terus meningkat sehingga menghambat aktivitas proses belajar mengajar di institusi pendidikan. Seperti halnya terdapat himbauan tersebut, langkah-langkah yang dilakukan oleh Dinas Pendidikan Kabupaten Lamongan adalah melakukan kerjasama dengan penyedia aplikasi Jagoapa dan Smart Foundation yang telah launching sebuah aplikasi pembelajaran yang bernama e-learning Jago Sinau dapat dimanfaatkan dalam membantu proses kemudahan pelajar dalam belajar mengajar di masa pandemi seperti sekarang, gebrakan baru di Kabupaten Lamongan dalam melakukan belajar mengajar melalui aplikasi Jagoapa mempunyai harapan besar agar para pelajar dapat melakukan belajar secara enjoy karena dimana dan kapan saja dapat dilakukan dengan materi pembelajaran yang sudah melalui proses penyesuaian dengan kurikulum pendidikan serta konteks dalam pendidikannya di Kabupaten Lamongan. Dinas Perpustakaan Daerah Kabupaten Lamongan juga meluncurkan sebuah aplikasi perpustakaan digital bernama iLamongan yang dapat digunakan untuk membaca e-book secara online maupun offline yang dilengkapi dengan e-Reader dan berbasis media sosial, sehingga 
pengguna dapat interaksi sosial dengan yang lainnya serta dapat merekomendasikan buku yang sedang atau telah dibaca kepada teman baru, maupun dapat menyampaikan ulasan buku sehingga memudahkan pelajar dalam melaksanakan pembelajaran daring.

\section{Metode Penelitian}

\subsection{Jenis penelitian}

Sebuah cara ilmiah yang didapatkan dengan data serta memiliki kegunaan untuk suatu tujuan tertentu merupakan pengertian dari metode penelitian yang di gagas oleh Sugiono. Sedangkan pendapat Soeyono mengenai pendekatan kuantitatif merupakan penelitian dengan jenis yang menggunakan perhitungan rata-rata, presentase, dan perhitungan statistik yang lain. Penelitian pada jurnal ini memilih jenis penelitian kuantitatif yang digunakan dalam data kemudian dianalisis berbentuk angka guna mengetahui ditolak ataupun diterimanya sebuah hipotesis sesuai dengan data yang digunakan dalam analisis statistik.

\subsection{Sumber Data Penelitian}

a. Data Primer

Perolehan data primer adalah langsung di dapatkan dari sumber, dengan cara mengumpulkan secara khusus yang berhubungan dengan masalah penelitian. Penelitian pada jurnal ini menggunakan data primer yaitu dari hasil pengisian kuesioner dari pelajar SMA/SMK/MA di Kabupaten Lamongan.

b. Data Sekunder

Membaca dari sumber bacaan berupa buku, jurnal, skripsi dan data di internet yang memiliki keterkaitan permasalahan dengan Strategi Peningkatan Mutu Pendidikan Pada Pelaksanaan Pembelajaran Daring Di Masa Pandemi COVID-19 (Survei Online : Pelajar SMA/SMK/MA di Kabupaten Lamongan merupakan perolehan data sekunder pada penelitian ini.

3.3 Metode Pengumpulan Data Penelitian 
Metode mengisi Kuesioner merupakan data dan informasi dalam penelitian ini yang diperoleh berupa pertanyaan serta pernyataan kepada para responden guna mendapatkan tanggapan. Isi dari kuesioner ini berupa pertanyaan serta jawaban singkat mengenai Strategi Peningkatan Mutu Pendidikan Pada Pelaksanaan Pembelajaran Daring Di Masa Pandemi COVID-19 (Survei Online : Pelajar SMA/SMK/MA di Kabupaten Lamongan). Beberapa pertanyaan diambil dari penelitian terdahulu serta dibuat sendiri oleh penulis dengan pencatatan skala likert yang digunakan serta diartikan untuk mengukur pendapat seseorang serta sikap seseorang mengenai fenomena sosial yang terjadi sekarang. Penulisan skala dalam jurnal ini menggunakan 2 nilai, antara lain :

$\begin{array}{ll}\text { Ya } & : 1 \\ \text { Tidak } & : 2\end{array}$

3.4 Populasi dan Sampel Penelitian

a. Populasi

Yang dimaksud dengan populasi adalah sebuah kumpulan data yang memiliki jenis sama dan berada di wilayah generalisasi serta mempunyai sebuah kualitas dan karakteristik yang baik untuk mempelajari subjek dam objek yang dijadikan sebagai kesimpulan. Dalam penelitian ini menggunakan populasi pelajar SMA/SMK/MA di Kabupaten Lamongan yaitu sebanyak 20 orang.

b. Sampel

Pendapat dari Chalid dan Ahmadi, mengenai sampel yang baik adalah digambarkan dengan keadaan populasi yang maksimal akan tetapi bukan hasil duplikat dari populasi. Jumlah sampel yang digunakan sebanyak 20 pelajar SMA/SMK/MA di Kabupaten Lamongan.

\section{Analisis dan Hasil}

a. Gambaran umum dampak covid-19 terhadap peningkatan mutu pendidikan dan keputusan kemendikbud memberlakukan pembelajaran daring

b. Deskripsi data responden 
Data dari responden ini dapat digunakan untuk meggambarkan keadaan responden dan juga sebagai tambahan informasi mengenai karakteristik responden yang diambil sebagai sampel adalah Pelajar SMA/SMK/MA di Kabupaten Lamongan

1. Nama Responden

Adapun data mengenai nama responden beberapa keluarga yang tinggal di Kabupaten Lamongan yang diambil sebagai sampel antara lain :

Tabel 4.1

\begin{tabular}{|c|c|c|c|c|c|}
\hline \multicolumn{6}{|c|}{ Nama } \\
\hline & & Frequency & Percent & Valid Percent & $\begin{array}{c}\text { Cumulative } \\
\text { Percent }\end{array}$ \\
\hline \multirow[t]{21}{*}{ Valid } & ACEA & 1 & 5,0 & 5,0 & 5,0 \\
\hline & $\mathrm{AFU}$ & 1 & 5,0 & 5,0 & 10,0 \\
\hline & AI & 1 & 5,0 & 5,0 & 15,0 \\
\hline & DP & 1 & 5,0 & 5,0 & 20,0 \\
\hline & E & 1 & 5,0 & 5,0 & 25,0 \\
\hline & ESP & 1 & 5,0 & 5,0 & 30,0 \\
\hline & $\mathrm{F}$ & 1 & 5,0 & 5,0 & 35,0 \\
\hline & FDP & 1 & 5,0 & 5,0 & 40,0 \\
\hline & $\mathrm{J}$ & 1 & 5,0 & 5,0 & 45,0 \\
\hline & KK & 1 & 5,0 & 5,0 & 50,0 \\
\hline & $\mathrm{L}$ & 1 & 5,0 & 5,0 & 55,0 \\
\hline & LA & 1 & 5,0 & 5,0 & 60,0 \\
\hline & MA & 1 & 5,0 & 5,0 & 65,0 \\
\hline & MS & 1 & 5,0 & 5,0 & 70,0 \\
\hline & MSH & 1 & 5,0 & 5,0 & 75,0 \\
\hline & $\mathrm{N}$ & 1 & 5,0 & 5,0 & 80,0 \\
\hline & $\mathrm{R}$ & 1 & 5,0 & 5,0 & 85,0 \\
\hline & RKN & 1 & 5,0 & 5,0 & 90,0 \\
\hline & $\mathrm{V}$ & 1 & 5,0 & 5,0 & 95,0 \\
\hline & $\mathrm{ZF}$ & 1 & 5,0 & 5,0 & 100,0 \\
\hline & Total & 20 & 100,0 & 100,0 & \\
\hline
\end{tabular}

Sumber : Pengolahan Data Penelitian, SPSS 16.0 
Dilihat dari tabel 4.1, inisial nama-nama responden sebanyak 20 orang, yang merupakan Pelajar SMA/SMK/MA di Kabupaten Lamongan.

2. Jenis Kelamin Responden

Tabel 4.2

\begin{tabular}{|ll|r|r|r|r|}
\hline & & & & \multicolumn{2}{c|}{$\begin{array}{c}\text { Jumulative } \\
\text { Percent }\end{array}$} \\
& & Frequency & Percent & Valid Percent & \multicolumn{1}{|c|}{35,0} \\
Vali & Laki-laki & 7 & 35,0 & 35,0 & 100,0 \\
d & Perempuan & 13 & 65,0 & 65,0 & \\
& Total & 20 & 100,0 & 100,0 & \\
\hline
\end{tabular}

Sumber : SPSS 16.0, Pengolahan Data Penelitian

Dilihat dari tabel 4.2, sebanyak 13 siswi yang mengisi kuesioner dan 7 siswa mengisi kuesioner yang merupakan Pelajar SMA/SMK/MA di Kabupaten Lamongan.

3. Kelas

Tabel 4.3

Kelas

\begin{tabular}{|l|r|r|r|r|}
\hline & & & & \multicolumn{2}{|c|}{$\begin{array}{c}\text { Cumulative } \\
\text { Percent }\end{array}$} \\
\hline Valid X & Prequency & Percent & Valid Percent & 5,0 \\
XI & 1 & 5,0 & 5,0 & 25,0 \\
XII & 4 & 20,0 & 20,0 & 100,0 \\
Total & 15 & 75,0 & 75,0 & \\
\hline
\end{tabular}

Sumber : SPSS 16.0, Pengolahan Data Kuesioner

Dilihat dari tabel 4.4, responden yang mengisi kuesioner kelas XII sebanyak 15 pelajar, yang sedang duduk di kelas XI terdapat 4 pelajar yang mengisi kuesioner, dan yang masih duduk di kelas $\mathrm{X}$ sebanyak 1 
responden yang mengisi kuesioner dan merupakan Pelajar SMA/SMK/MA di Kabupaten Lamongan.

4. Sekolah

Tabel 4.4

Sekolah

\begin{tabular}{|l|r|r|r|r|}
\hline & Frequency & Percent & $\begin{array}{c}\text { Valid } \\
\text { Percent }\end{array}$ & $\begin{array}{c}\text { Cumulative } \\
\text { Percent }\end{array}$ \\
\hline Valid $\begin{array}{l}\text { SMA/SMK/MA } \\
\text { Kabupaten Lamongan }\end{array}$ & 20 & 100,0 & 100,0 & 100,0 \\
\hline
\end{tabular}

Sumber : SPSS 16.0, Pengolahan Data Penelitian

Dilihat dari tabel 4.4, responden yang mengisi kuesioner adalah Pelajar SMA/SMK/MA di Kabupaten Lamongan, yang terdiri dari SMAN 1 Sekaran, SMAN 1 Sukodadi, SMK PGRI 1 Sukodadi, SMAN 3 Lamongan, SMKN 2 Lamongan, SMA Pancamarga Lamongan, MAN 1 Lamongan.

c. Deskripsi data penelitian

Setiap variabel akan di deskripsikan menggunakan Frequecy Table dengan perolehan hasil penelitian berupa pengisian angket atau kuesioner dari jawaban responden pelajar SMA/SMK/MA di Kabupaten Lamongan sebanyak 20 responden yang diambil sebagai sampel. Dalam penelitian jurnal ini menggunakan berbagai variabel, diantaranya terdiri dari variabel independen (bebas) berupa; (1) Apakah kamu senang belajar daring, jika tidak apa yang membuat kamu tidak senang; (2) Apakah ada kesulitan ketika belajar daring; (3) Apakah dengan belajar daring membuat kamu lebih rajin belajar; (4) Apakah belajar daring lebih memudahkan kamu dalam hal ketika ada tugas; (5) Apakah ada perbedaan yang kamu rasakan antara pembelajaran daring dengan pembelajaran sebelum Covid-19; (6) Apakah setuju, jika belajar daring akan diberlakukan secara permanen; (7) Apakah ada keluhan ketika 
kamu belajar daring, jika iya, sebutkan; (8) Apa yang kamu rasakan ketika belajar daring; (9) Apa pendapatmu, jika pembelajaran daring akan diterapkan permanen; (10) Menurut kamu, bagaimana cara meningkatkan agar giat belajar di masa pandemi COVID-19.

Pada angket kuesioner di dalamnya terdapat pernyataan yang menggambarkan mengenai tanggapan terhadap pertanyaan pada setiap variabel. Pernyataan tersebut berupa jawaban dengan kategori, Ya, Tidak, dan pertanyaan dengan jawaban uraian secara singkat Hasil kuesioner ini merupakan penilaian dari responden berdasarkan apa yang mereka rasakan atau alami.

a. Variabel apakah kamu senang belajar daring, jika tidak apa yang membuat kamu tidak senang?

Tabel 4.5

Apakah_senang_belajar_daring

\begin{tabular}{|rl|r|r|r|r|}
\hline & & & & \multicolumn{2}{c|}{$\begin{array}{c}\text { Cumulative } \\
\text { Percent }\end{array}$} \\
\hline Valid & Ya & 8 & 40,0 & 40,0 & 40,0 \\
& Tidak & 12 & 60,0 & 60,0 & 100,0 \\
& Total & 20 & 100,0 & 100,0 & \\
\hline
\end{tabular}

Jika_tidak_kenapa

\begin{tabular}{|l|r|r|r|r|}
\hline & Frequency & Percent & \multicolumn{1}{|c|}{$\begin{array}{c}\text { Valid } \\
\text { Percent }\end{array}$} & $\begin{array}{c}\text { Cumulative } \\
\text { Percent }\end{array}$ \\
\hline $\begin{array}{l}\text { Valid- } \\
\quad 8\end{array}$ & 40,0 & 40,0 & 40,0 \\
$\quad \begin{array}{l}\text { Banyak pelajaran yang } \\
\text { kurang faham }\end{array}$ & 1 & 5,0 & 5,0 & 45,0 \\
Bosan & 1 & 5,0 & 5,0 & 50,0 \\
$\begin{array}{l}\text { Karena banyak pelajaran } \\
\text { yang tidak masuk otak }\end{array}$ & 1 & 5,0 & 5,0 & 55,0 \\
$\begin{array}{l}\text { Karena menghabiskan kuota } \\
\text { internet }\end{array}$ & 1 & 5,0 & 5,0 & 60,0 \\
$\quad \begin{array}{l}\text { Karena terkendala kuota dan } \\
\text { akses internet }\end{array}$ & 1 & 5,0 & 5,0 & 65,0 \\
\hline
\end{tabular}




\begin{tabular}{|l|r|r|r|r|}
\hline Karena, banyak godaannya & 1 & 5,0 & 5,0 & 70,0 \\
Kurang wawasan & 1 & 5,0 & 5,0 & 75,0 \\
Menghabiskan kuota & 1 & 5,0 & 5,0 & 80,0 \\
Pelajaran yang disampaikan & 1 & 5,0 & 5,0 & 85,0 \\
guru sulit dipahami & & & & \\
Saya lebih sulit untuk & 1 & 5,0 & 5,0 & 90,0 \\
memahami pelajaran dan & & & & \\
materi yang diberikan guru & & & & \\
Terkadang pengajar hanya & 1 & 5,0 & 5,0 & 95,0 \\
menyediakan materi, tidak & & & & \\
menjelaskan materi tersebut & 1 & 5,0 & 5,0 & 100,0 \\
Tidak ada sinyal & 20 & 100,0 & 100,0 & \\
Total & &
\end{tabular}

Sumber : SPSS 16.0, Pengolahan Data Penelitian

Diihat dari tabel 4.5, responden yang menjawab tidak senang dengan belajar daring sebanyak 12 responden dengan berbagai macam alasan, sedangkan yang menyukai belajar daring sebanyak 8 responden.

b. Variabel apakah ada kesulitan ketika belajar daring?

Tabel 4.6

Apakah_ada_kesulitan_belajar_daring

\begin{tabular}{|ll|r|r|r|r|}
\hline & & & Valid & Cumulative \\
Percent & Percent \\
\hline Valid & Ya & 11 & 55,0 & 55,0 & 55,0 \\
& Tidak & 9 & 45,0 & 45,0 & 100,0 \\
& Total & 20 & 100,0 & 100,0 & \\
\hline
\end{tabular}

Sumber : SPSS 16.0, Pengolahan Data Penelitian

Dilihat dari tabel 4.6, responden yang menjawab ada kesulitan ketika belajar daring sebanyak 11 responden, dan sebnyak 9 responden yang tidak kesulitan ketika belajar daring. 
c. Variabel apakah dengan belajar daring membuat kamu lebih rajin belajar?

Tabel 4.7

Apakah_dengan_belajar_daring_lebih_rajin

\begin{tabular}{|c|c|c|c|c|c|}
\hline & & Frequency & Percent & $\begin{array}{c}\text { Valid } \\
\text { Percent } \\
\end{array}$ & $\begin{array}{c}\text { Cumulative } \\
\text { Percent }\end{array}$ \\
\hline \multirow[t]{3}{*}{ Valid } & $\mathrm{Ya}$ & 7 & 35,0 & 35,0 & 35,0 \\
\hline & Tidak & 13 & 65,0 & 65,0 & 100,0 \\
\hline & Total & 20 & 100,0 & 100,0 & \\
\hline
\end{tabular}

Sumber : SPSS 16.0, Pengolahan Data Penelitian

Dilihat dari tabel 4.7 , responden yang menjawab pada pertanyaa apakah dengan belajar daring menjadi lebih rajin, sebanyak 13 responden menjawab iya, dan sebanyak 7 responden yang menjawab tidak.

d. Variabel apakah belajar daring lebih memudahkan kamu dalam hal ketika ada tugas?

Tabel 4.8

Apakah_belajar_daring_memudahkan_tugas

\begin{tabular}{|ll|r|r|r|r|}
\hline & & & \multicolumn{1}{|c|}{$\begin{array}{c}\text { Valid } \\
\text { Percent }\end{array}$} & $\begin{array}{c}\text { Cumulative } \\
\text { Percent }\end{array}$ \\
\hline Valid & Ya & 10 & 50,0 & 50,0 & 50,0 \\
& Tidak & 10 & 50,0 & 50,0 & 100,0 \\
& Total & 20 & 100,0 & 100,0 & \\
\hline
\end{tabular}

Sumber : SPSS 16.0, Pengolahan Data Penelitian

Dilihat dari tabel 4.8, responden yang menjawab iya pada pertanyaan belajar daring memudahkan dalam hal ketika ada tugas yaitu sebanyak 10 responden, dan 10 responden lagi menjawab belajar daring tidak memudahkan dalam hal ketika ada tugas. 
e. Variabel apakah ada perbedaan yang kamu rasakan antara pembelajaran daring dengan pembelajaran sebelum Covid-19?

Tabel 4.9

Apakah_ada_perbedaan_pembelajaran_daring_dan_luring

\begin{tabular}{|ll|r|r|r|r|}
\hline & & & & & $\begin{array}{c}\text { Cumulative } \\
\text { Percent }\end{array}$ \\
\hline \multirow{2}{*}{ Valid } & Ya & 19 & 95,0 & 95,0 & 95,0 \\
& Tidak & 1 & 5,0 & 5,0 & 100,0 \\
& Total & 20 & 100,0 & 100,0 & \\
\hline
\end{tabular}

Sumber : Pengolahan Data Penelitian, SPSS 16.0

Dilihat dari tabel 4.9, responden yang menjawab ada perbedaan anatara pembelajaran daring dan luring sebanyak 19 responden, dan hanya 1 responden yang mejawab tidak ada perbedaan.

f. Variabel apakah setuju, jika belajar daring akan diberlakukan secara permanen?

Tabel 4.10

Apakah_setuju_daring_permanen

\begin{tabular}{|c|c|c|c|c|c|}
\hline & & Frequency & Percent & $\begin{array}{c}\text { Valid } \\
\text { Percent }\end{array}$ & $\begin{array}{c}\text { Cumulative } \\
\text { Percent }\end{array}$ \\
\hline \multirow[t]{3}{*}{ Valid } & Ya & 3 & 15,0 & 15,0 & 15,0 \\
\hline & Tidak & 17 & 85,0 & 85,0 & 100,0 \\
\hline & Total & 20 & 100,0 & 100,0 & \\
\hline
\end{tabular}

Sumber : SPSS 16.0, Pengolahan Data Penelitian

Dilihat dari tabel 4.10, sebanyak 3 responden yang setuju apabila belajar daring diberlakukan secara permanen, dan sebanyak 17 responden yang tidak setuju dengan pemberlakuan belajar daring permanen. 
g. Variabel apakah ada keluhan ketika kamu belajar daring, jika iya, sebutkan?

Tabel 4.11

Apakah_ada_keluhan_belajar_daring

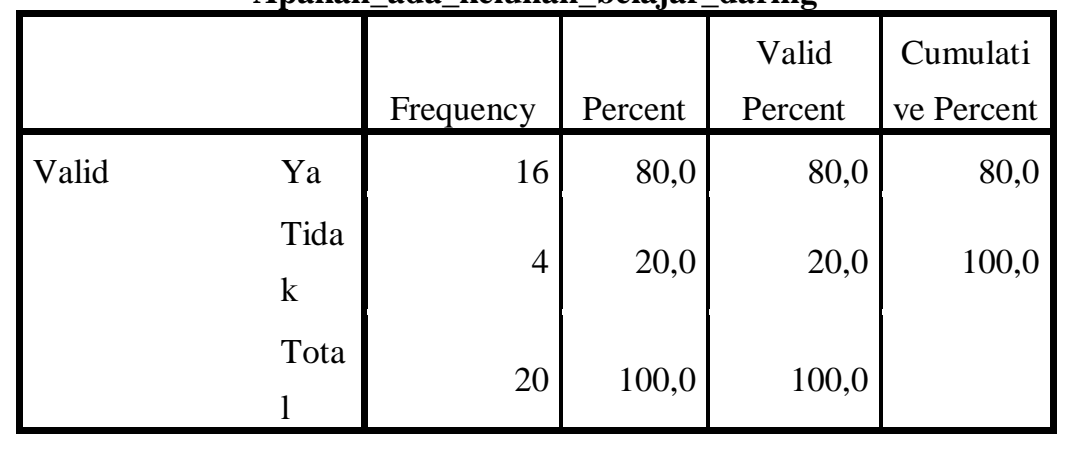

Jika_iya_sebutkan

\begin{tabular}{|c|c|c|c|c|c|}
\hline & & Frequency & Percent & Valid Percent & $\begin{array}{c}\text { Cumulative } \\
\text { Percent }\end{array}$ \\
\hline $\mathrm{Va}$ & - & 4 & 20,0 & 20,0 & 20,0 \\
\hline \multirow{18}{*}{ lid } & Akses kuota dan jangkauan & & & & \\
\hline & internet & & J, & $\pi, 0$ & 2,0 \\
\hline & Jaringan kurang stabil & 1 & 5,0 & 5,0 & 30,0 \\
\hline & Kadang sinyal yang ngak & & & & \\
\hline & mendukung kadang gapunya & 1 & 5,0 & 5,0 & 35,0 \\
\hline & kuota & & & & \\
\hline & Kendala pada paket data & & & & \\
\hline & perbulannya, malas dan & 1 & 5,0 & 5,0 & 40,0 \\
\hline & kesulitan memahami materi & & & & \\
\hline & Kendala sinyal sehingga gak & & & & \\
\hline & efektif dalam menangkap & & & & \\
\hline & ilmu, susah cari tempat yg & 1 & 5,0 & 5,0 & 45,0 \\
\hline & nyaman, susah komunikasi & & & & \\
\hline & dengan bebas & & & & \\
\hline & Kuota & 1 & 5,0 & 5,0 & 50,0 \\
\hline & Kuota, waktu, sulit diskusi & & & & \\
\hline & dengan teman-teman dan & 1 & 5,0 & 5,0 & 55,0 \\
\hline & karena slow respon & & & & \\
\hline
\end{tabular}




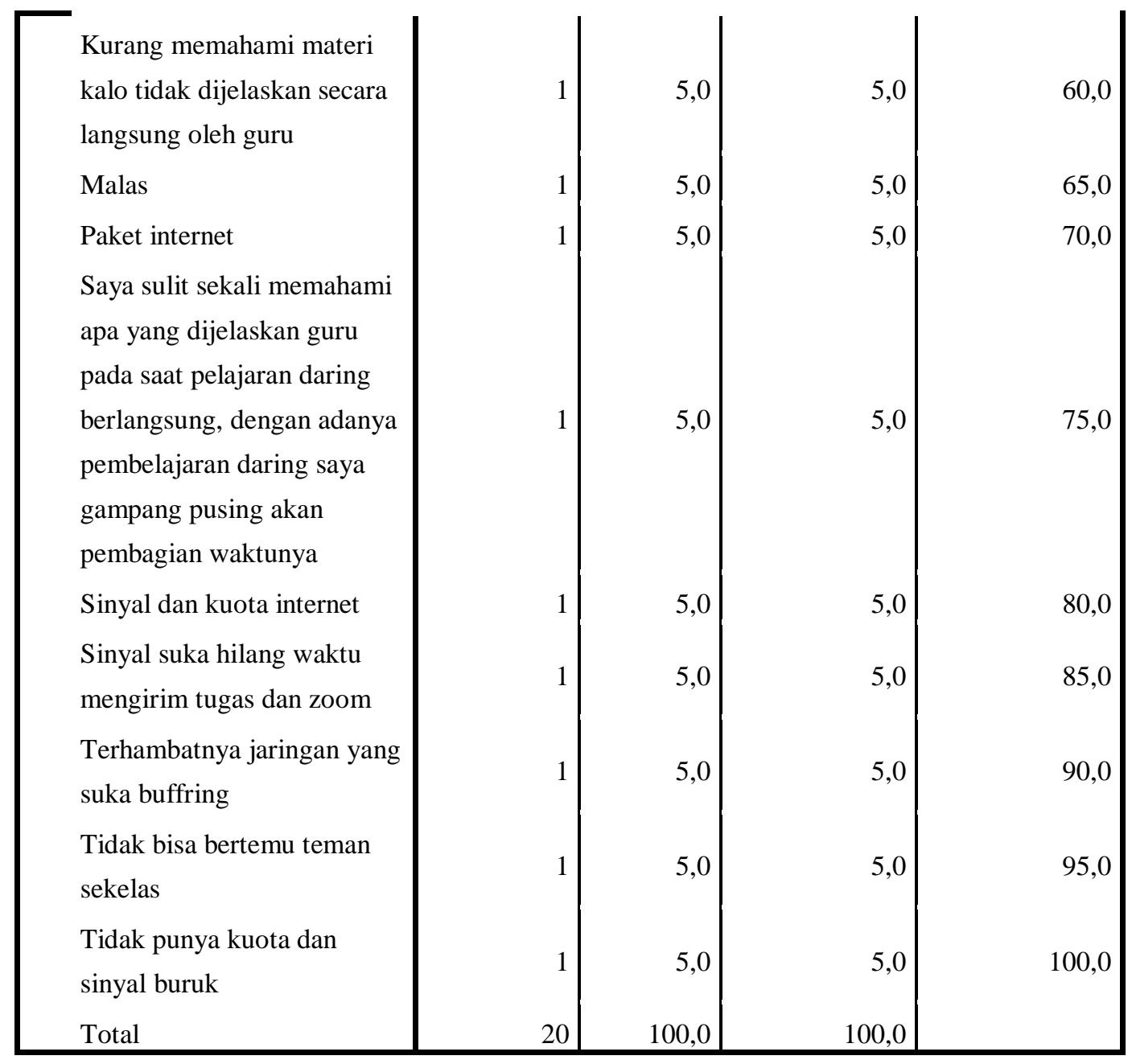

o

Sumber : SPSS 16.0, Pengolahan Data Penelitian

Dilihat dari tabel 4.11 mengenai pertanyaan apakah ada keluhan ketika belajar daring, sebanyak 16 responden menjawab iya dengan berbagai alasan utama jaringan, dan sebanyak 4 responden yang tidak mengeluh ketika belajar daring.

h. Variabel apa yang kamu rasakan ketika belajar daring!

Tabel 4.12

\section{Perasaan_ketika_belajar_daring}




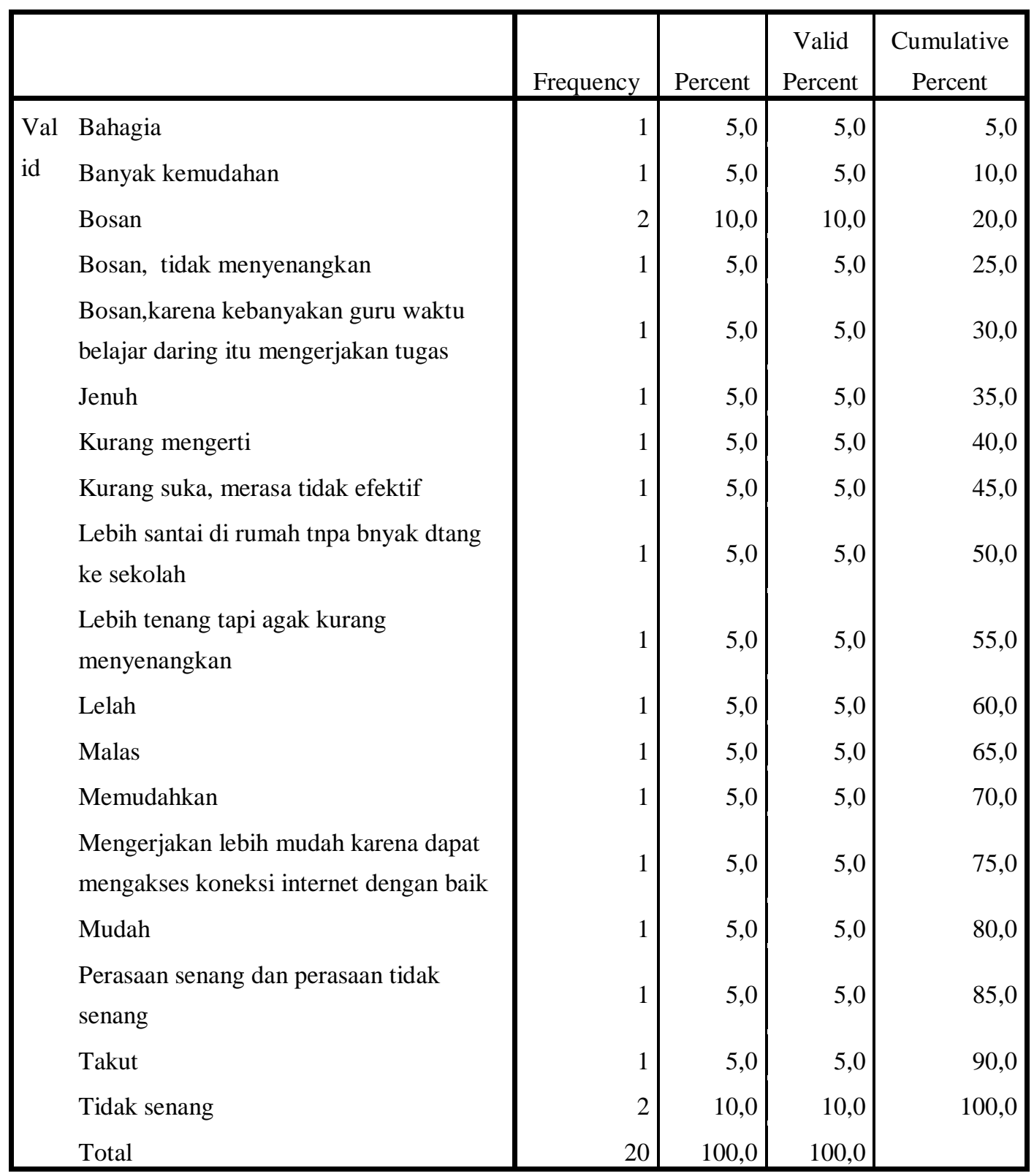

\section{Sumber : SPSS 16.0, Pengolahan Data Penelitian}

Dilihat dari tabel 4.12 mengenai pertanyaan apa yang dirasakan ketika belajar daring, semua jawaban mayoritas sama dengan alasan bosan, jenuh, kurang difahami, lelah, malas, dan sebagainya.

i. Variabel apa pendapatmu, jika pembelajaran daring akan diterapkan permanen! 
Tabel 4.13

Pendapat_apabila_daring_permanen

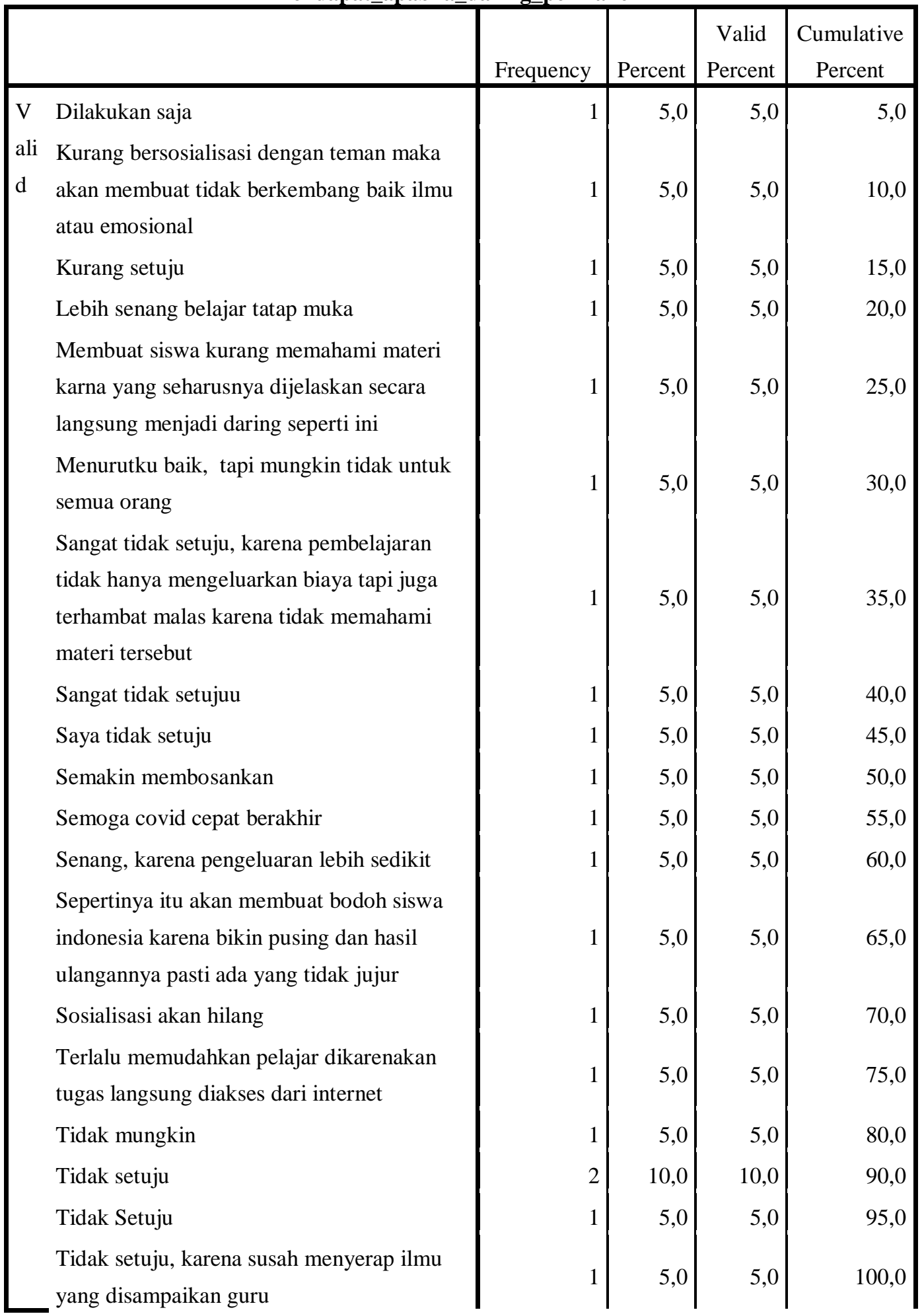




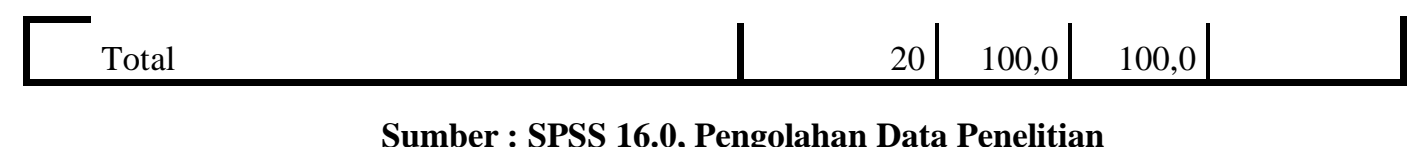

Dilihat dari tabel 4.13 pendapat responden mengenai apabila pembelajaran daring diterapkan permanen, dijawab dengan berbagai macam argument dengan mayoritas jawaban kurang setuju karena tidak faham, pasrah, tidak setuju.

j. Variabel menurut kamu, bagaimana cara meningkatkan agar giat belajar di masa pandemi COVID-19!

Tabel 4.14

Cara_meningkatkan_giat_belajar_saat_covid

\begin{tabular}{|c|c|c|c|c|c|}
\hline & & Frequency & Percent & $\begin{array}{c}\text { Valid } \\
\text { Percent } \\
\end{array}$ & $\begin{array}{l}\text { Cumulati } \\
\text { ve Percent }\end{array}$ \\
\hline \multirow{9}{*}{$\begin{array}{l}\text { V } \\
\text { ali } \\
\text { d }\end{array}$} & $\begin{array}{l}\text { Banyak banyak refreshing, biar ngga } \\
\text { sumpek }\end{array}$ & 1 & 5,0 & 5,0 & 5,0 \\
\hline & Belajar dengan media inernet & 1 & 5,0 & 5,0 & 10,0 \\
\hline & $\begin{array}{l}\text { Dengan cara membuat list pembelajaran } \\
\text { supporting team sangar diperlukan }\end{array}$ & 1 & 5,0 & 5,0 & 15,0 \\
\hline & Diberi kuota internet yang banyak & 1 & 5,0 & 5,0 & 20,0 \\
\hline & Ikhlas dalam belajar & 1 & 5,0 & 5,0 & 25,0 \\
\hline & $\begin{array}{l}\text { Jaringan internet lebih di perbaiki lagi } \\
\text { agar dpt menjangkau semua wilayah } \\
\text { Indonesia }\end{array}$ & 1 & 5,0 & 5,0 & 30,0 \\
\hline & $\begin{array}{l}\text { Kita harus menimbulkan rasa suka } \\
\text { terhadap belajar, membuat tarjet dalam } \\
\text { belajar juga memotivasi diri }\end{array}$ & 1 & 5,0 & 5,0 & 35,0 \\
\hline & $\begin{array}{l}\text { Lebih memanajemen waktu agar tidak } \\
\text { terganggu dengan kerjaan rumah, dan } \\
\text { perbanyak melihat motivasi yang bisa } \\
\text { meningkatkan semangat }\end{array}$ & 1 & 5,0 & 5,0 & 40,0 \\
\hline & $\begin{array}{l}\text { Lebih sering membaca buku dan latihan } \\
\text { soal sendiri }\end{array}$ & 1 & 5,0 & 5,0 & 45,0 \\
\hline
\end{tabular}


Lihat video pembelajaran

Makan

Memanfaatkan media sosial, internet dsb

sebagai sarana belajar dirumah

Meningkatkan rasa ingin tahu

Menurutku kita harus sadar dengan

kewajiban kita

Metode pembelajaran yang menarik dan asik

Rajin membaca

Semangat

Tidak ada

Ya, Jangan malas

Yakni dengan sering seringnya membaca beberapa artikel di internet

Total

\begin{tabular}{r|r|r|r|}
1 & 5,0 & 5,0 & 50,0 \\
1 & 5,0 & 5,0 & 55,0 \\
1 & 5,0 & 5,0 & 60,0 \\
1 & 5,0 & 5,0 & 65,0 \\
1 & 5,0 & 5,0 & 70,0 \\
1 & & & \\
& & & \\
1 & 5,0 & 5,0 & 75,0 \\
1 & 5,0 & 5,0 & 80,0 \\
1 & 5,0 & 5,0 & 85,0 \\
1 & 5,0 & 5,0 & 90,0 \\
1 & 5,0 & 5,0 & 95,0 \\
1 & & & \\
1 & 5,0 & 5,0 & 100,0 \\
20 & 100,0 & 100,0 & \\
\hline
\end{tabular}

Sumber : SPSS 16.0, Pengolahan Data Penelitian

Dilihat dari tabel 4.14 pendapat responden mengenai tips dan trik untuk meningkatkan giat belajar di masa pandemi antara lain memanfaatkan internet sebagai saran belajar di rumah, sadar dengan kewajiban sebagai pelajar, sering membaca artikel atau bahan bacaan lainnya di internet, dan sebagainya.

\section{Kesimpulan dan Saran}

\subsection{Kesimpulan}

Penelitian ini melakukan analisis untuk menjelaskan Strategi Peningkatan Mutu Pendidikan Pada Pelaksanaan Pembelajaran Daring Di Masa Pandemi Covid-19 (Survei Online: Pelajar SMA/SMK/MA di Kabupaten Lamongan) dengan menggunakan data SPSS 16.0, yang terdiri dari beberapa variabel (1) Apakah kamu senang belajar daring, jika tidak apa yang membuat kamu tidak senang; (2) Apakah ada kesulitan ketika belajar daring; (3) Apakah dengan 
belajar daring membuat kamu lebih rajin belajar; (4) Apakah belajar daring lebih memudahkan kamu dalam hal ketika ada tugas; (5) Apakah ada perbedaan yang kamu rasakan antara pembelajaran daring dengan pembelajaran sebelum Covid-19; (6) Apakah setuju, jika belajar daring akan diberlakukan secara permanen; (7) Apakah ada keluhan ketika kamu belajar daring, jika iya, sebutkan; (8) Apa yang kamu rasakan ketika belajar daring; (9) Apa pendapatmu, jika pembelajaran daring akan diterapkan permanen; (10) Menurut kamu, bagaimana cara meningkatkan agar giat belajar ketika pada masa pandemi COVID-19 terjadi.

Disimpulkan dari pembahasan yang dijelaskan pada sebelumya, bahwa strategi peningkatan mutu pendidikan dalam pelaksanaan pembelajaran daring di Kabupaten Lamongan adalah telah diluncurkan aplikasi pembelajaran yang dilakukan secara kerjasama antara Dinas Pendidikan Kabupaten Lamongan penyedia aplikasi Jagoapa dan Smart Foundation berupa aplikasi yang bernama e-learning Jago Sinau. Dinas Perpustakaan Daerah Kabupaten Lamongan juga meluncurkan sebuah aplikasi perpustakaan digital bernama iLamongan yang dapat digunakan untuk membaca e-book secara online maupun offline.

\subsection{Saran}

Saran penulis kepada pembaca jurnal ini adalah agar pembaca dapat mencari dan mempelajari referensi lain terkait topik yang menjadi pembahasan dalam jurnal, agar dapat memahami topik secara mendalam dan menyeluruh serta lengkap. Hal ini diharapkan kepada pembaca agar bisa mengulas kembali lebih detail mengenai pentingnya strategi dalam meningkatkan mutu pendidikan untuk masa depan yang cemerlang. 


\section{DAFTAR PUSTAKA}

Retrieved Juni 13, 2021, from Covid-19 pandemic data: https://covid19.go.id/.

Dabbagh, N. (2007). The Online Learner : Pedagogical Implications and Characteristics. Contemporary Issues in Technology and Teacher Education, 7 (3), hal 217-226.

Kompas, R. (n.d.). Retrieved Juni 13, 2021, from pembelajaran daring di Lamongan: https://regional.kompas.com/read/2020/11/10/22120431/bantu-pembelajaran-siswasaat-pandemi-covid-19-dinas-pendidikan-lamongan?page=all .

Mukbulloh, D. (2011). Manajemen Mutu Pendidikan Islam. Jakarta: PT. Raja Grafindo Persada,.

News, F. Retrieved Juni 13, 2021, from keluhan belajar daring: https://faktualnews.co/2020/11/28/soal-keluhan-belajar-daring-disdik-lamongansarankan-pakai-internet-di-kantor-desa/226070/

Sari, F. \&. (2020). Pembelajaran Online di Tengah Pandemi Covid-19. Indonesian Journal Of Educational Science (IJES), Volume 02 No 02.

Tribunnews, S. Retrieved Juni 13, 2021, from kendala belajar daring di Lamongan: https://surabaya.tribunnews.com/2020/07/30/problem-pada-jaringan-untuk-belajardaring-di-lamongan-siswa-disarankan-gunakan-internet-desa

Zhang, e. a. (2004). Can e-learning replace classroom learning? Communications of the ACM, Vol. 47 No.5. 